\title{
Surface rupture and hazard characteristics of the Wenchuan Ms 8.0 earthquake, Sichuan, China *
}

\author{
Rong-Jun Zhou ${ }^{1}$, Yong $\mathrm{Li}^{2}$, Liang Yan ${ }^{2}$, Jian-Cheng Lei ${ }^{1}, \mathrm{Yi} \mathrm{Zhang}^{2}$, Yu-Lin He ${ }^{1}$, \\ Long-Shen Chen ${ }^{3}$, Xiao-Gang Li ${ }^{1}$, Shi-Yuan Wang ${ }^{1}$, You-Qing Ye ${ }^{1}$, Yu-Fa Liu ${ }^{1}$, \\ Chuan-Chuan Kang ${ }^{1}$, Tian-Yong $\mathrm{Ge}^{1}$, Qiang He ${ }^{1}$, Wei Huang ${ }^{1}$

\footnotetext{
${ }^{1}$ Institute of Engineering Seismology of Earthquake Administration of Sichuan Province, Chengdu, China

${ }^{2}$ State Key Laboratory of Oil and Gas Reservoir Geology and Exploitation, Chengdu University of Technology, Chengdu, China; yanliang1003@163.com

${ }^{3}$ The University of Hong Kong, Department of Geology, Hong Kong, China
}

Received 23 December 2009; revised 14 January 2010; accepted 25 January 2010.

\begin{abstract}
Longmen Shan is located the special joint between Tibetan Plateau inland in the west and Yangtze craton in the east. Consisting of a series of parallel imbricated thrust, it develops, from the west to the east, the MaoxianWenchuan, Beichuan-Yingxiu and PengxianGuanxian faults. The Wenchuan earthquake is a thrust with strike-slip type, and thre surface ruptures are located on the Beichuan-Yingxiu fault zone and Pengxian-Guanxian fault zone. The surface rupture on the Beichuan-Yingxiu fault shows the thrust and dextral slip characteristic. The maximum vertical displacement of the surface rupture is about $10.3 \mathrm{~m}$ and the maximum right-lateral displacement is about $5.85 \mathrm{~m}$. Though the vertical displacements and the horizontal displacements in the different segments have certain differences, as a whole, the ratio of the vertical displacement and the horizontal displacement is close to 1:1. The surface rupture on the Pengxian-Guanxian fault shows thrust and dextral characteristic. The rates of vertical displacements and the horizontal displacements ones on the most other segments are between 1:3 and 1:2. So the Beichuan- Yingxiu fault is a dextral-slip and thrust fault and the average vertical displacement is equal to the average horizontal displacement, while the Pengxian- Guan xian fault is thrust fault with a little dextral-slip component. The total intensity area above VI degree of the Wenchuan earthquake is about 333000 $\mathrm{km}^{2}$. The high earthquake intensity line stretches to $\mathrm{N} 40-50^{\circ} \mathrm{E}$ along Longmen Shan tectonic belt.
\end{abstract}

\footnotetext{
* This research was supported by China National Natural Science Foundation grant 40841010, 40972083 and China National Science and Technology supporting Plan Foundation grant 2006BAC13B02-07, 2006BAC13B01-604.
}

The rate of the long axis and the minor is between $8: 1$ and 10:1. Three $X I$ intensity regions are isolated in distribution. It presents a multipoint instantaneous characteristic of the rupture.

Keywords: Wenchuan earthquake; Longmen Shan; Surface rupture; Hazard; Sichuan; China

\section{INTRODUCTION}

According to the record of China earthquake networks, on $12^{\text {th }}$ May, 2008, a huge earthquake Ms8.0 struck Yingxiu town in Wenchuan county, Sichuan province $\left(31^{\circ} 00^{\prime} \mathrm{N}, 103^{\circ} 24^{\prime} \mathrm{E}\right)$. The earthquake took place at 14:28:04(Beijing time) and the depth of its hypocenter is about 14 kilometers. This earthquake with high magnitude and shallow hypocenter made an astonished attack on Longmen Shan area, which is located in the west of Sichuan basin, resulting in tremendous casualties and property losses. The earthquake occurred on Longmen Shan tectonic belt at the eastern margin of the Tibet Plateau. Since the late Cenozoic, the thrust-dextral movement of Longmen Shan tectonic belt led to Longmen Shan Mt.'s fast uplifting in opposition to Sichuan basin. Within the range of 50 kilometers along Longmen Shan tectonic belt, topographical fall exceeds 5 kilometers, which produces mountains and canyons region [1-5]. The special terrain and geology condition increased the damage of this earthquake.

As soon as the earthquake occurred, the writer went to Earthquake-stricken area to carry out an on-the-spot investigation for more than twenty days, accompanying the earthquake emergency job team of China Earthquake Administration. Some replenish investigations were carried out later. Mountain fall, the earth splits, changes of mountains and rivers caused by the earthquake made Longmen Shan full of distress everywhere, which was 
elegant and pretty in the past. The enormous casualties and property losses that the earthquake brought about are furthermore grieved. Being greatly shocked and regretful, we illuminate the first step survey results of surface rupture and hazard characteristic of the earthquake and our thoughts about it in this paper, providing a reference for our fraternity. Especially, this paper was devoted to those who had been died or disappeared in this destructive earthquake.

\section{THE SURFACE RUPTURE OF THE WENCHUAN EARTHQUAKE}

The Longmen Shan tectonic belt stretches through the central of Sichuan province at $\mathrm{N} 40-50^{\circ} \mathrm{E}$ orientation and forms the boundary of the Songpan-Garzê orogenic belt and the Yangtze Platform[1,6-8]. In late Triassic, the closure of Neo-Tethys Ocean resulted in the Longmen Shan tectonic thrusting from northwest to southeast. It controlled the formation and development of the Cenozonic foreland basin in the southwest of the Sichuan basin. There is a suit of mauve late Triassic - Cenozonic clastic rock of river and lake facies. Since late Cenozonic, with the closure of Neo-Tethys Ocean and fast-uplift of Qinghai-Tibet Plateau, neotectonic activities of Longmen Shan tectonic belt have aroused many researchers' interest. Avouac and Tapponnier [9] believed that Longmen Shan tectonic belt shortens sustainably at the NW-SE orientation, with a rate of $20 \mathrm{~mm} / \mathrm{yr}$ since late Cenozoic. But through field works, Burchfiel [1] found that there was lack of geological evidence for a large-scale shortening of Longmen Shan tectonic belt and the west of Sichuan basin. Data measured by the Global Positioning System(GPS) cross Longmen Shan tectonic belt shows that the shortening rate of it is only $4.0 \pm 2.0 \mathrm{~mm} / \mathrm{yr}$, in opposition to that of Sichuan basin [10]. However, England and Molnar [11] pointed out that convergence between India plate and Eurasia plate was reflected by a simple dextral-shear motion in the east margin of the Qinghai-Tibet Plateau. Furthermore, Li Yong [3] believed that uplift of the Longmen Shan was produced under the co-effect of the dextral motion and erode load-off of the Longmen Shan tectonic belt.

The Longmen Shan tectonic belt is composed of Maoxian-Wenchuan fault (the north-eastern segment is called Pingwu-Qingchuan fault), Beichuan-Yingxiu fault and Pengxian-Guanxian fault. There is a blind fault in the front of the Longmen Shan Mountain (Figure 1). All of these faults are late Pleistocence-Holocene active faults. There are divergent opinions on the late Quaternary activities of the Longmen Shan tectonic belt among different scholars. Zhou [12] believe that the Longmen Shan tectonic belt shows a thrust and dextral slip since late Quaternary. The slip rate of single fault is about $1 \mathrm{~mm} / \mathrm{yr}$, and the vertical component of displacement is equivalent to the horizontal. However, Densmore [5] believe that the average vertical slip rates of Beichuan-Yingxiu fault and Pengxian-Guanxian fault are less than $1 \mathrm{~mm} / \mathrm{yr}$. The horizontal slip rates of the faults are between $1 \mathrm{~mm} / \mathrm{yr}$ and $10 \mathrm{~mm} / \mathrm{yr}$. And the faults show a dextral-slip characteristic. The Wenchuan Ms8.0 earthquake, on $12^{\text {th }}$ May, 2008, produced coseismic displacements along BeichuanYingxiu fault and Pengxian-Guanxian fault coinstantaneously. After the earthquake, a lot of geological experts [13-23] carried out detailed investigations about the surface rupture, caused by the Wenchuan earthquake, in the Longmen Shan area. Therefore, it provides a good study and a validated example for the late Quaternary activity of the Longmen Shan tectonic belt.

\subsection{The Surface Rupture on the Beichuan-Yingxiu Fault}

Beichuan-Yingxiu fault is also called Beichuan fault [5] and is the major causative fault of the Wenchuan Ms8.0 earthquake on $12^{\text {th }}$ May, 2008. The surface rupture on this fault started near by Yingxiu town in Wenchuan county and extended to the north-east. It is about 220 kilometers long, and crosses Hongkou town, Longmen Shan town, Donglin temple, the north of Hongbai town, Qingping town, Chaping town, Leigu town, Beichuan town, Chenjiaba village, Fenghuang village of Guixi town and Pingtong town, break down near Shikanzi village in the east of Nanba town, Pingwu county.

1) The surface rupture of the Wenchuan Earthquake in Yingxiu town

The epicenter of Wenchuan Ms8.0 earthquake is close to Yingxiu town. The surface rupture of the earthquake crosses the north of Yingxiu town in $\mathrm{N} 60-70^{\circ} \mathrm{E}$ orientation. According to the different section features of the surface ruptures, it can be inferred that inclination of the fault is about $40-50^{\circ}$. In the north-west of Yingxiu town, the vertical displacement of the national highway (G213) is about 2 meters, and the dextral displacement is about 1.7 meters. A small waterfall was produced on a river bed (Figure 2). Zhou [12] described that the vertical displacement of Minjiang river's terrace IV caused by Beichuan-Yingxiu fault was about 40 meters. And the bending fault produced a normal fault graben on the hanging wall of the fault. This earthquake produced two surface rupture zones on the fault scarp (close to its top) with a horizontal distance of 6 meters. The vertical displacement is about 0.75 meters and the horizontal displacement is 1.1 meters at the low elevation place. At the place with higher elevation, the vertical displacement and the horizontal one are 2.4 meters, 1.9 meters, respectively. And the total vertical displacement is 3.15 meters; the total horizontal displacement is 3.0 meters (Figure 3). At the normal fault graben, it produced the new normal fault scarp and tensile fractures. It is consistent with the previous cognition. This phenomenon indicates that the fault scarp on terrace IV is the accumula 


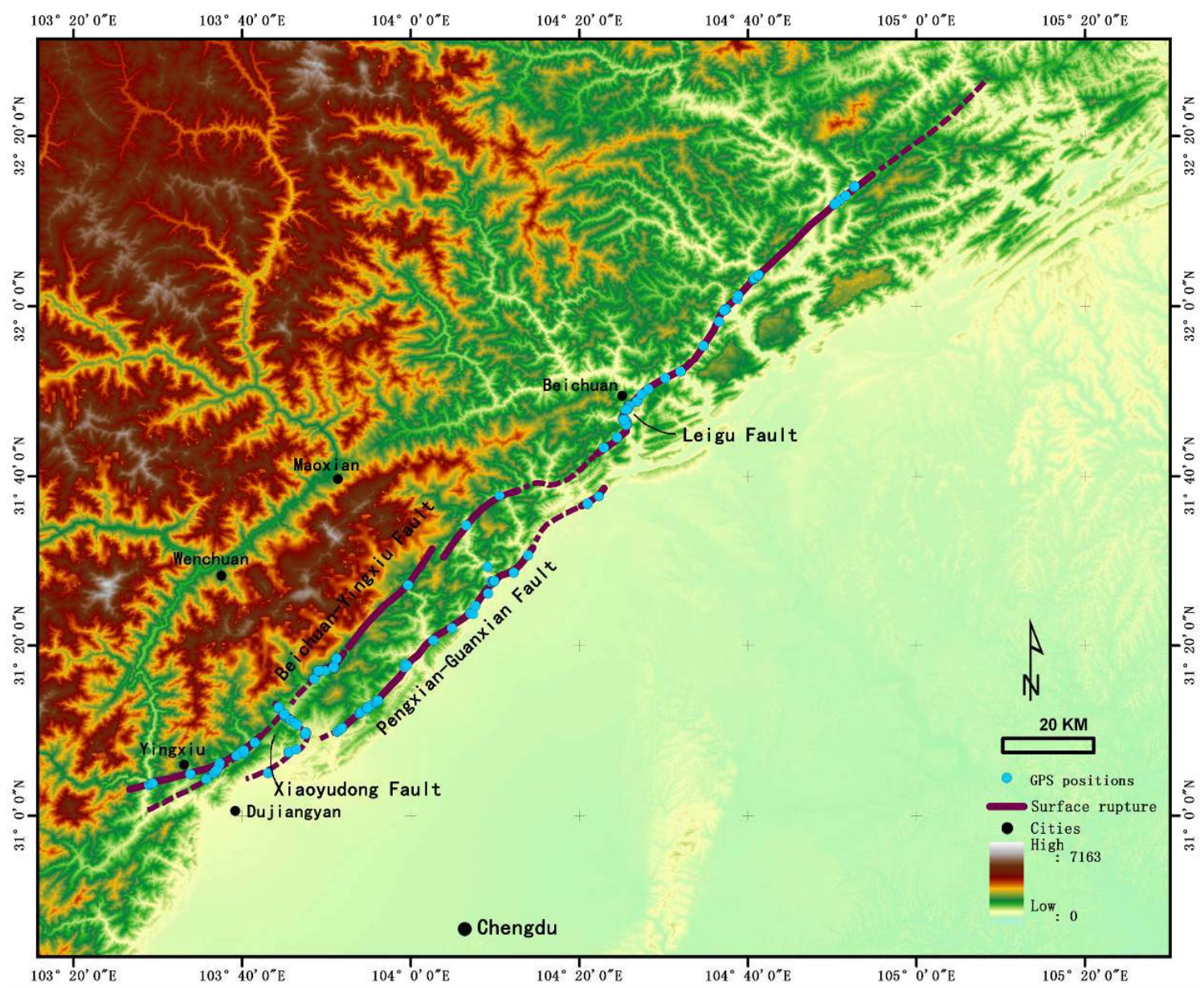

Figure 1. Distribution map for the surface rupture of the Wenchuan earthquake in Longmen Shan.

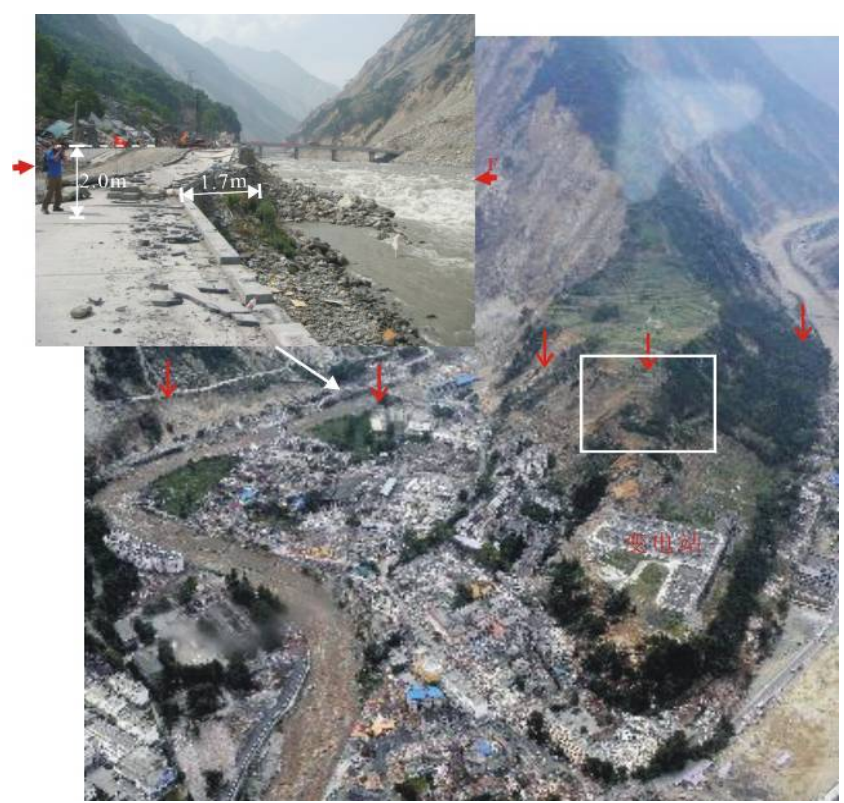

Figure 2. Sketch for the surface rupture of the Wenchuan earthquake in Yingxiu county. 


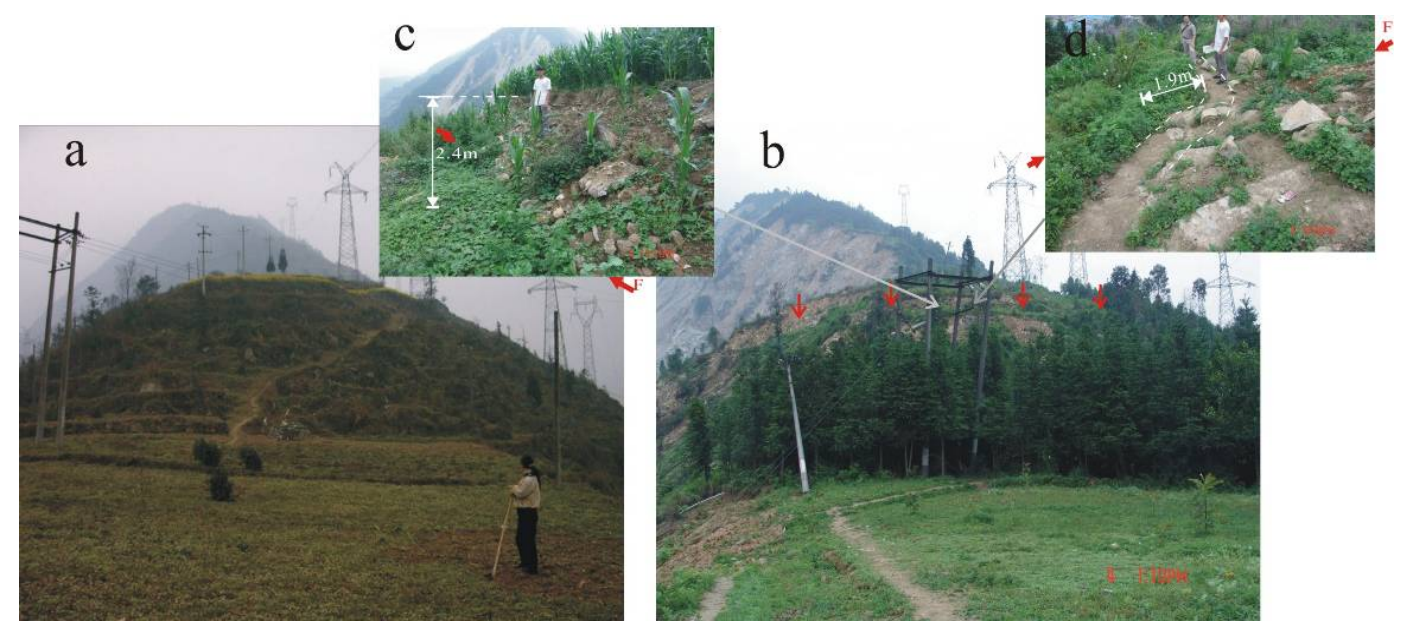

Figure 3. Fault scarp on the terrace IV of Minjiang river in the north of Yingxiu town. The photograph (a) was shot on May, 2002. The photograph (b) was shot on July, 2008. The photograph c shows the vertical component of the surface rupture. The photograph d shows the dextral horizontal displacement of the path.
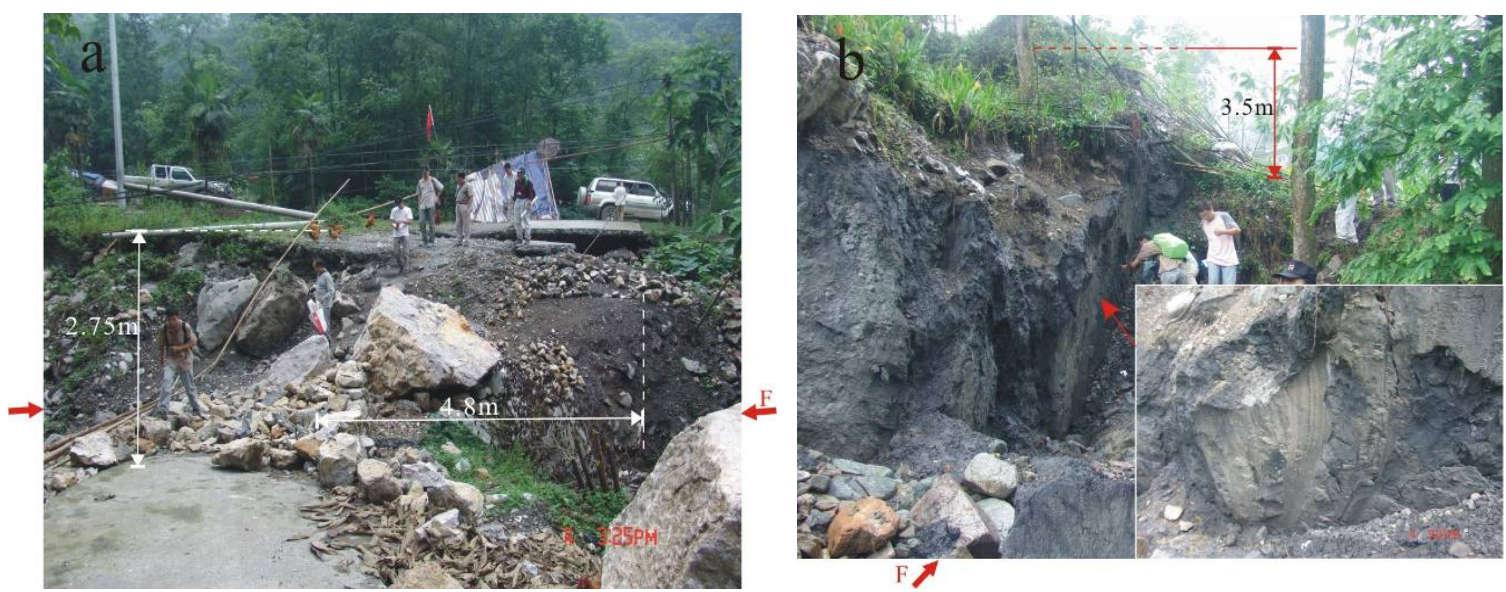

Figure 4. The surface rupture of the Wenchuan earthquake in Hongkou region, Dujiangyan city. (a) the displacements of the road at Shenxigou village; (b) the fault scarps at Bajiao temple.

tive displacement produced by several movement events of the fault since late Quaternary and it has been undergone a-long-term denudated and back-off process.

2) The surface rupture of the Wenchuan Earthquake in Hongkou town

The surface rupture extends at $\mathrm{N} 50-60^{\circ} \mathrm{E}$ orientation along the north-west bank of Baisha River near Hongkou town in Dujiangyan city. It is about 16 kilometers long. The maximum vertical displacement and the maximum horizontal one are also about 5 meters. At Shenxigou village, the surface rupture made a path displace with a vertical component of 2.75 meters and a horizontal component of 4.8 meters. Near Bajiaomiao paper mill with a distance of 8 kilometers to the spot, the road, the toft, tarrence I, the wash-land and the latter-day river bed are all displaced 3.5 meters. The fault developed in the Triassic coal stratum. There are two different phases scarps on the fault plane, and the side angle of the horizontal one is $43^{\circ}$. The scarp produced by this earthquake is vertical approximately (Figure 4).

3) The surface rupture of the Wenchuan Earthquake in Donglin temple.

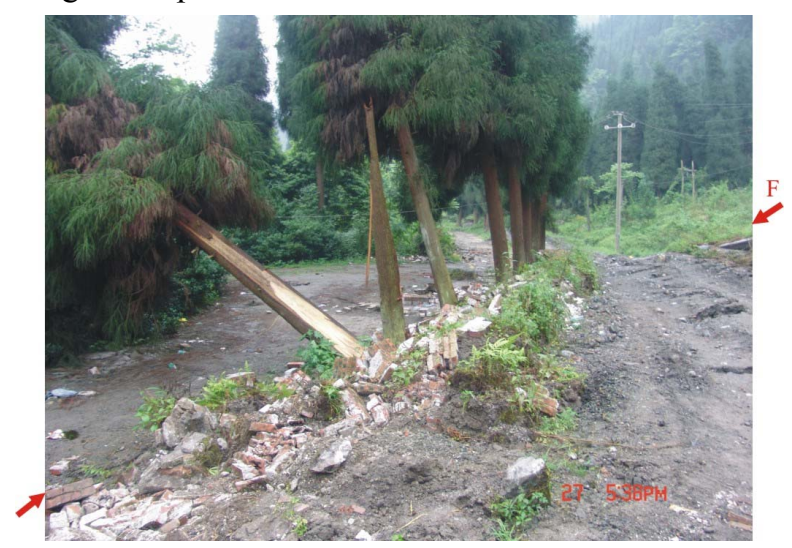

Figure 5. Dislocation of road and split of pine tree in Donglin temple, Longmen Shan town, Pengzhou county. 
At Donglin temple, 6 kilometers away to Longmen Shan town at NE orientation(Baishui river), the surface rupture zone extends at $\mathrm{N} 45^{\circ} \mathrm{E}$ orientation, intersects with a pathway with a small angle. The vertical displacement of the pathway is 2.2 meters. A gully was displaced vertically and produced drop water. There is a row of pine trees along one side of the road. According to the local residents' description, the road and pine trees are straight before the earthquake occurred. The road and pine trees along the surface rupture zone produced right-lateral coseismic distortion. The horizontal displacement is $3.6 \pm$ $1.0 \mathrm{~m}$. The instantaneous offset of the fault resulted in the pine trees inclined obviously, which are on the fault scarp. One of the pine trees split and fell down because the effect of gravitation overlaid (Figure 5).

4) The surface rupture of the Wenchuan Earthquake in Leigu town, Beichuan county

Near Leigu town of Beichuan county, the BeichuanYingxiu fault divides into four branch faults arrange in left-step en echelon. The result in the II proluvial fan and streams vertical and dextral offset. The Gaitou hill in the left-step area uplifted and Qianjiang river course was changed $[3,5,12]$. The surface rupture of this earthquake at Pingshang village in the north of Leigu town stretches to $\mathrm{N} 40^{\circ} \mathrm{E}$, and made a list of gullies, pathways, proluvial fan, road, water pipes, terrain I and river bed produce vertical and right-lateral displacements (Figure 6). The surface rupture shows that the north-west wall of the fault uplifted and the south-east wall declined correspondingly. Specially, Zhou [12] found a fault scarp with the height of $22.5 \mathrm{~m}$ and a gully with the right-lateral displacement of $1.6 \mathrm{~m}$ before on the II level pluvial fan [12] (Figure 7). At the same place, the surface rupture outcrops along the preexisted fault scarp. The maximum vertical displacement is $4.5 \mathrm{~m}$. The displacements of gully and a pathway are $1.6 \mathrm{~m}$ and the right-lateral dislocations of them are $1.43 \mathrm{~m}$ (Figure 8). At Zhaojiagou village with a distance of $500 \mathrm{~m}$ to the spot, the vertical displacement of terrace I is about $6.5 \mathrm{~m}$ and the right-lateral one is $5.85 \mathrm{~m}$. But the landslip maybe impacted on the precision of the displacements measurement here.

The Liulin village in the west of Leigu town is near the left-step area of the fault. There, the show of the surface is more complicated. From north to south, the trend of the surface rupture strikes from NE-trending to SN-trending and NWW-trending (Figure 9).The NS-trending surface rupture shows the vertical and left-lateral offset respectively. The vertical displacement and the left-lateral offsets of a water slot are $1.9 \mathrm{~m}, 1.3 \mathrm{~m}$ respectively. The NWW-trending surface rupture shows the vertical and right-lateral offset. The foundation of a house is cut off by two cracks. The vertical displacements of two are $1.5 \mathrm{~m}, 0.5 \mathrm{~m}$ respectively. And the right-lateral offsets of them are 1.3, $0.3 \mathrm{~m}$ respectively (Figure 10).

5) The surface rupture of the Wenchuan Earthquake in
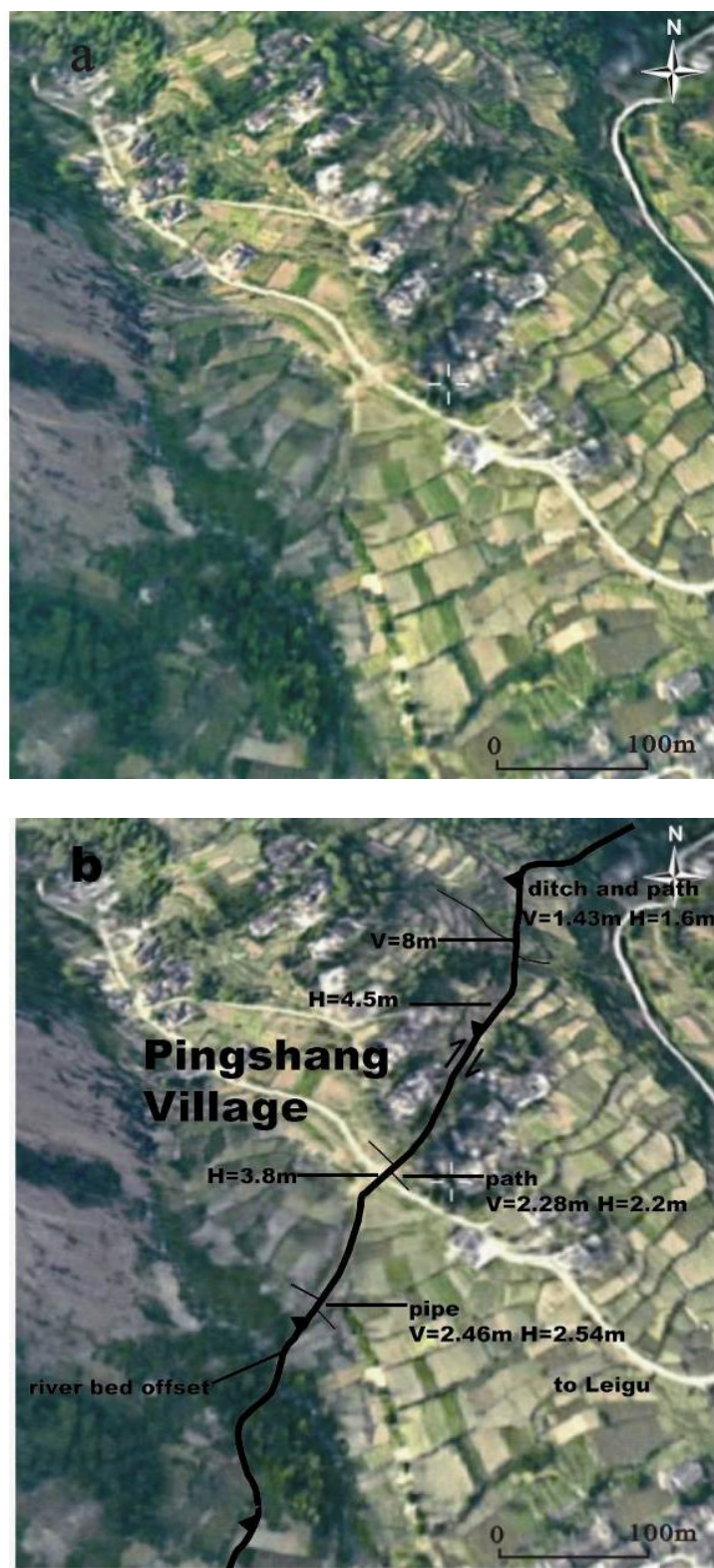

Figure 6. Distribution map for the surface ruptures of the Wenchuan Earthquake in Pingshang village, Leigu town. (a) the unworked airscape; (b) the worked airscape; the black lines figure the distribution of the surface rupture, the black-sawtooth lines shows the hanging wall of the rupture; V: horizontal offset; $\mathrm{H}$ : vertical offset.

Maoba village, Beichuan county

Maoba village is about $300 \mathrm{~m}$ away to the northeast of Beichuan county. The surface rupture of BeichuanYingxiu fault is $\mathrm{N} 40-50^{\circ} \mathrm{E}$ trending, and its vertical displacements $4.7 \mathrm{~m}-10.3 \mathrm{~m}$, which turns out to be a great scarp with a characteristic of antithetic fault (Figure 11(a)). The rupture incised the plat in the front of a building with a vertical offset of $10.3 \pm 0.2 \mathrm{~m}$, and a horizontal offset of $3.8 \mathrm{~m}$ (Figure 11(b)). About $200 \mathrm{~m}$ away to the northeast of this point, the rupture cut a hummock. 


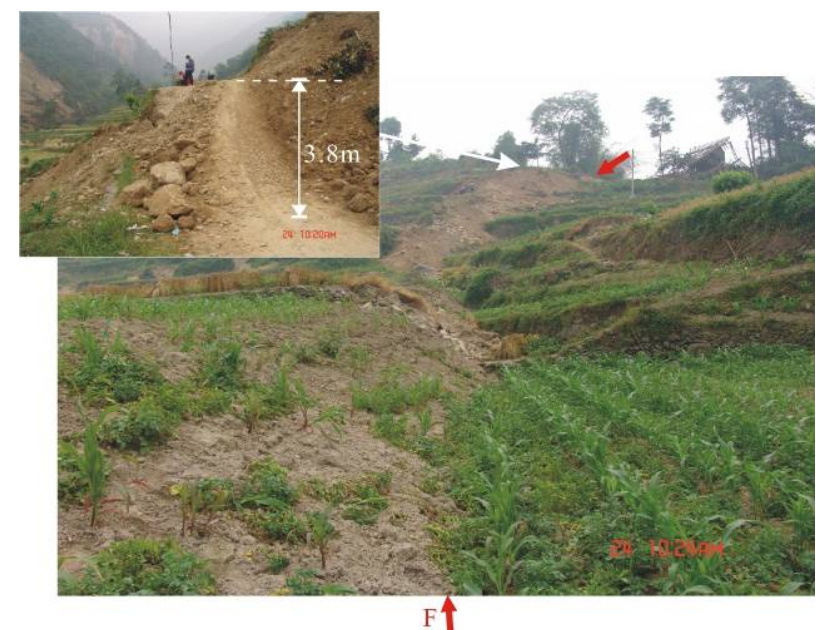

Figure 7. Displacements of the surface ruptures on the terrace I and road in Pingshang village, Leigu town.

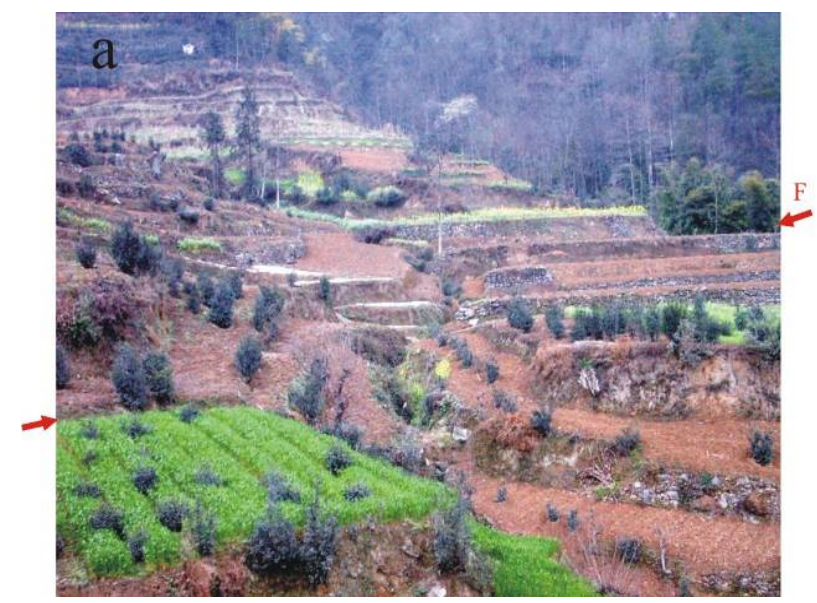

As effects of the right lateral component, there is a triangular facet of fault in the edge of the hummock, and the right-lateral offset of a field is $5.3 \mathrm{~m}$ (Figure 11(c))

6) The surface rupture of the Wenchuan Earthquake in Chenjiaba village

Chenjiaba village is about 15 kilometers away to the northeast of Beichuan county. Here, the surface rupture is about $200 \mathrm{~m}$ long. The other segments of the surface rupture are covered by landslides. The rupture is $\mathrm{N} 35^{\circ} \mathrm{E}$ trending and incised the river bed, floodplain, terrace I and the pathway. The vertical displacements of them are $2.0 \mathrm{~m}, 1.7 \mathrm{~m}$ respectively. The right-lateral offset of them are $1.6 \mathrm{~m}, 1.35 \mathrm{~m}$ respectively (Figure 12(a)).

7) The surface rupture of the Wenchuan Earthquake in Fenghuang village, Guixi town

Fenghuang village is about 2 kilometers away to the northwest of Guixi town. The vertical displacement of a

Figure 8. Displacements of the surface ruptures on the terrace II and gully in Pingshang village, Leigu town. (a) The photograph was shot on April, 2002; (b) The photograph was shot on July, 2008; the arrowhead shows the location of surface rupture, the northern-western side of the rupture obviously uplifted relative to the photograph a.
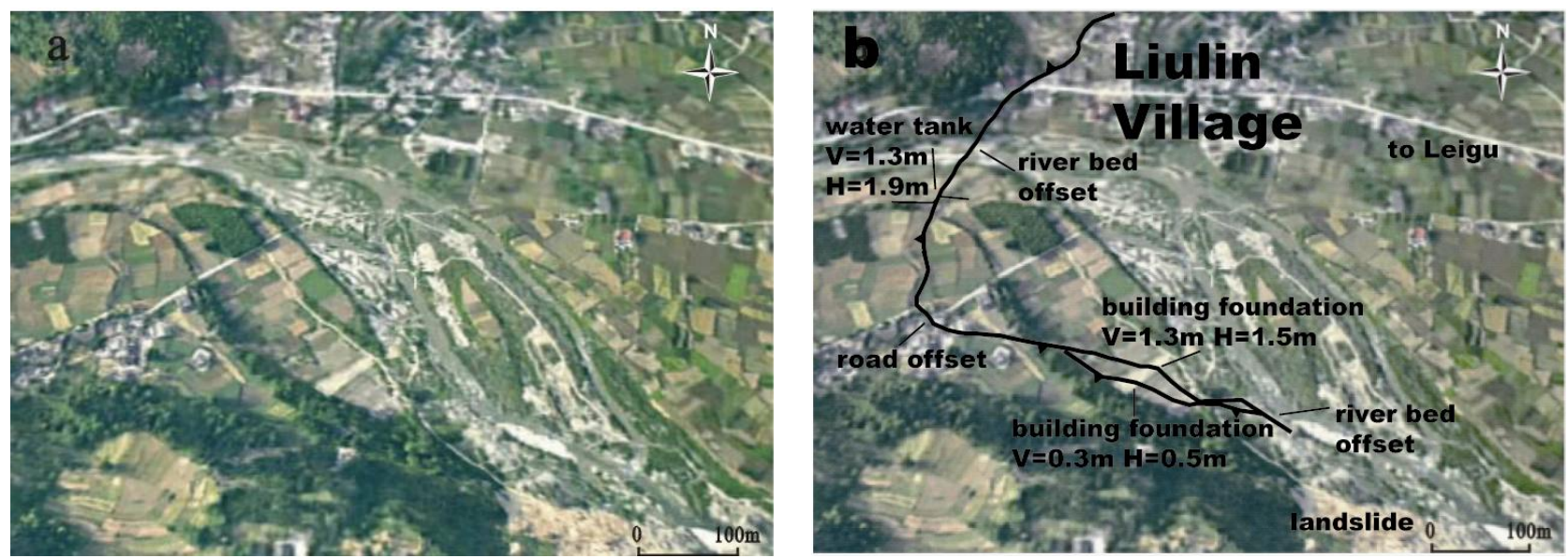

Figure 9. Distribution map for the surface rupture of the Wenchuan Earthquake in Liulin village, Leigu town. (a) the unworked airscape; (b) the worked airscape; the black lines figure the distribution of the surface rupture, the black-sawtooth lines shows the hanging wall of the rupture; V: vertical offset; H: horizontal offset. 

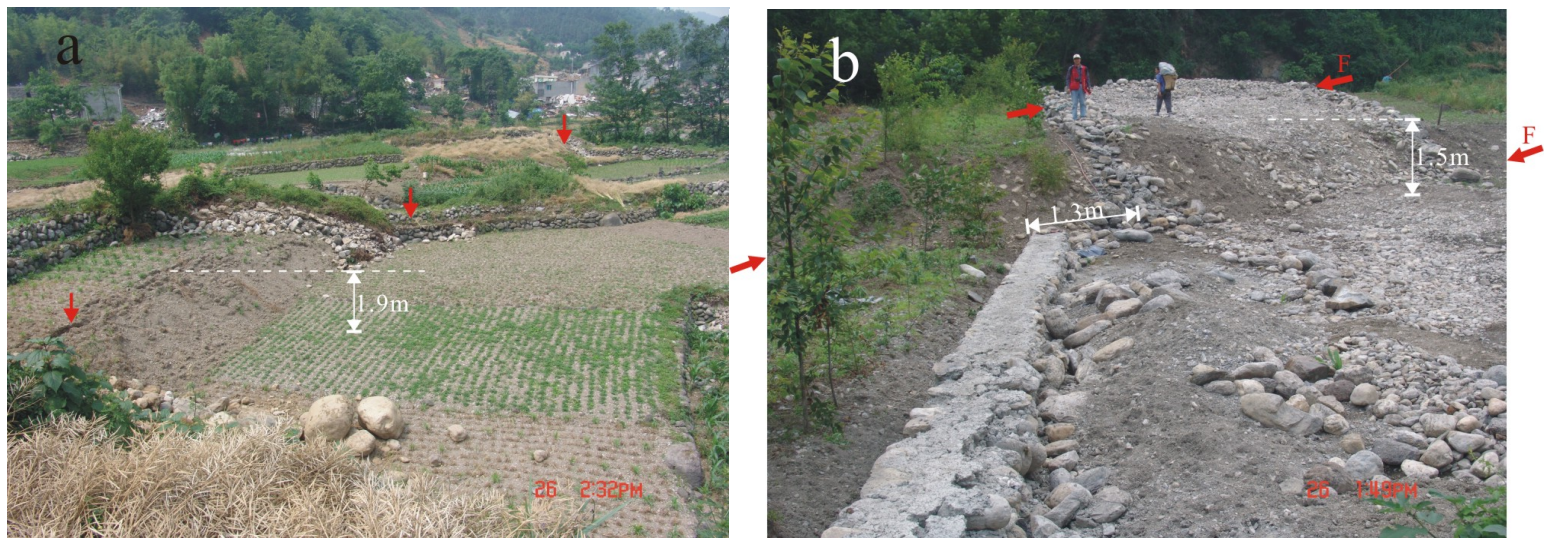

Figure 10. Displacements of the surface ruptures in the west of Leigu town. (a) the vertical displacements of the terrace I and the water slot, the arrowhead shows the locate of the water slot; (b) the offset on the foundation of the house.
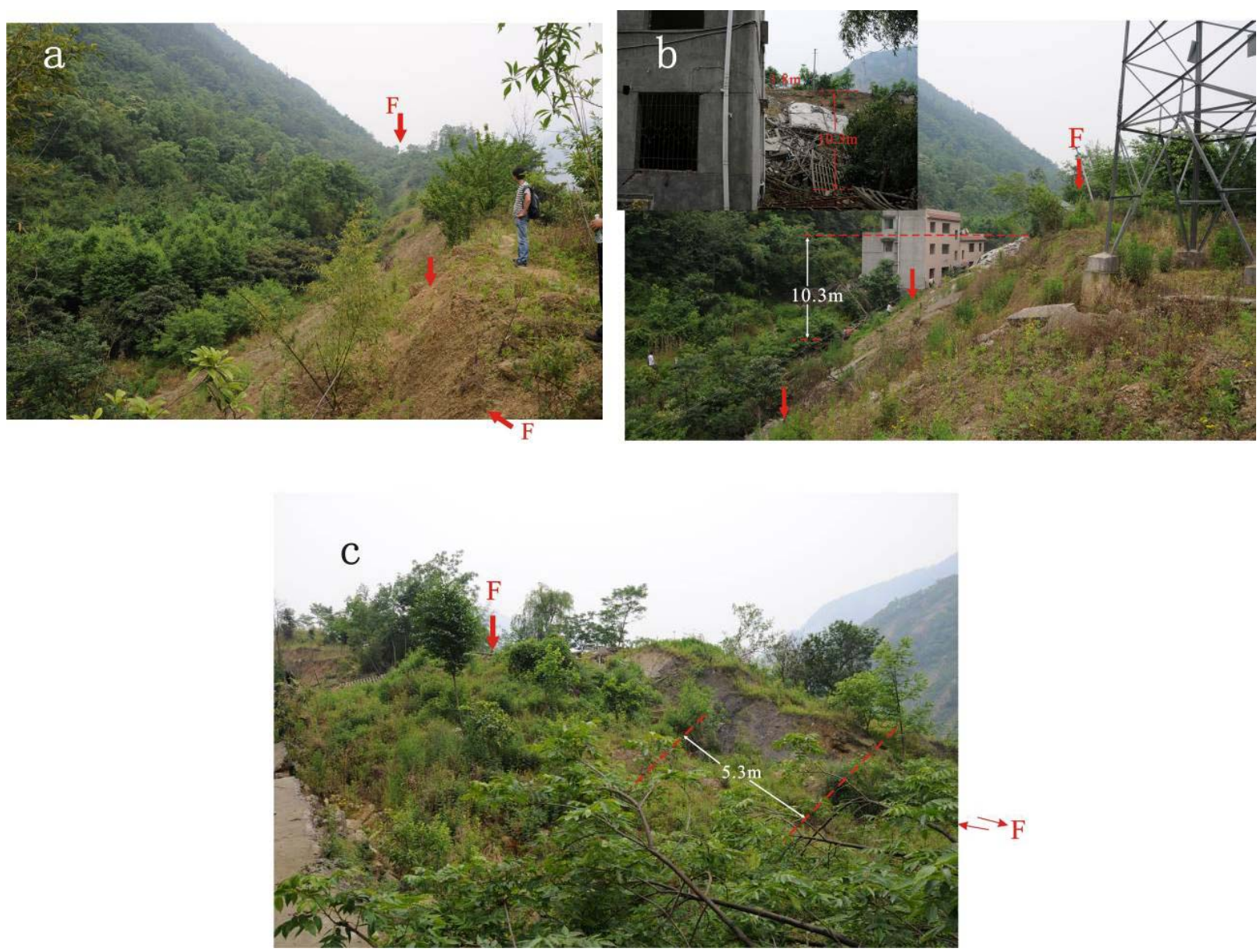

Figure 11. The surface rupture of the Wenchuan Earthquake in Maoba village, Beichuan county. (a) the vertical displacements in Maoba village; (b) the vertical and horizontal displacements of the plat in the front of a building; (c) the right-lateral offset of the field.

pathway in the village is about $2.5 \mathrm{~m}$ and the right-lateral offset of it is $2.4 \mathrm{~m}$. The terrace of the river, floodplain and riverbed were incised by the rupture in the southwest of the spot. The fractured zone of bedrock outcrops near the bank of river. The vertical displacement of a pathway on the floodplain is about $2.1 \mathrm{~m}$ and the rightlateral of it is about $1.78 \mathrm{~m}$ (Figure 12(b)).

8) The surface rupture of the Wenchuan Earthquake in Pingtong town

The surface rupture near the Pingtong town is about 


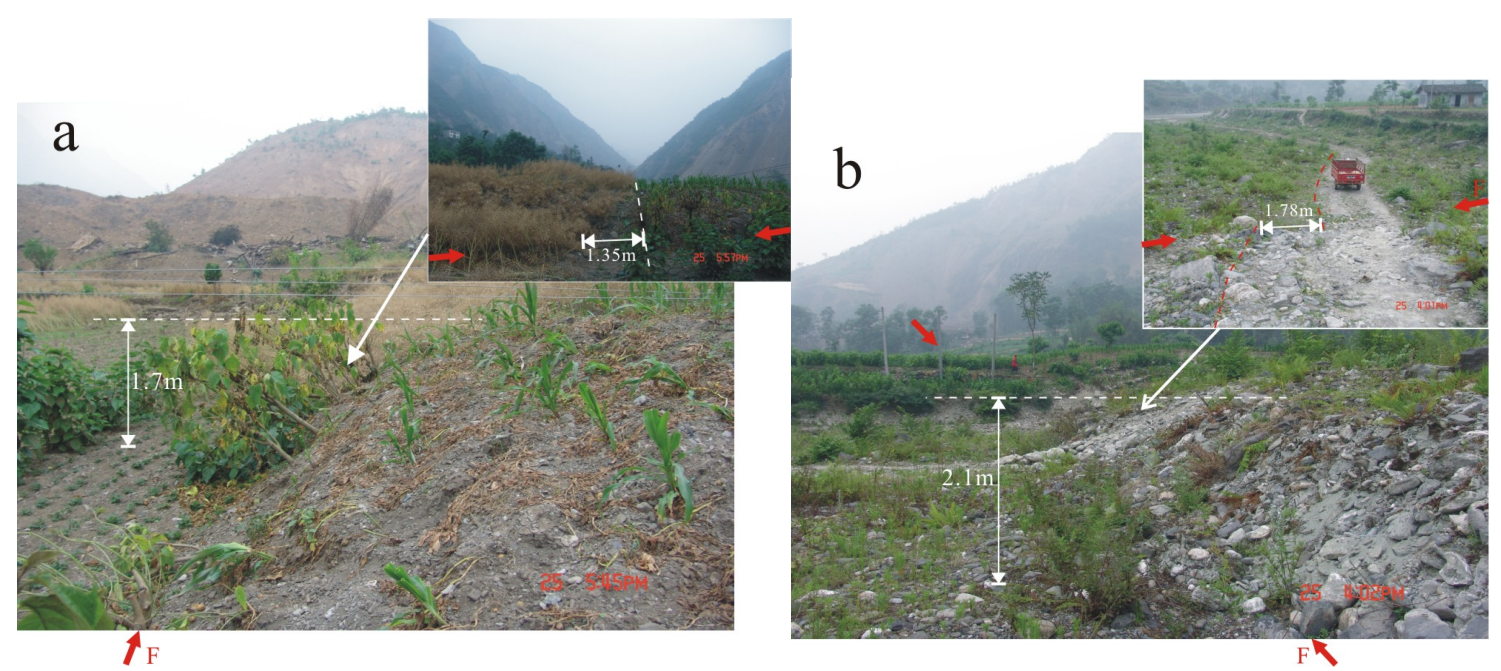

Figure 12. The surface ruptures of the Wenchuan Earthquake in Chenjiaba town and Fenghuang village, Guixi town. (a). the displacement of the terrace I in Chenjiaba village; (b). the displacement of a pathway and the floodplain in Fenghuang village, Guixi town.

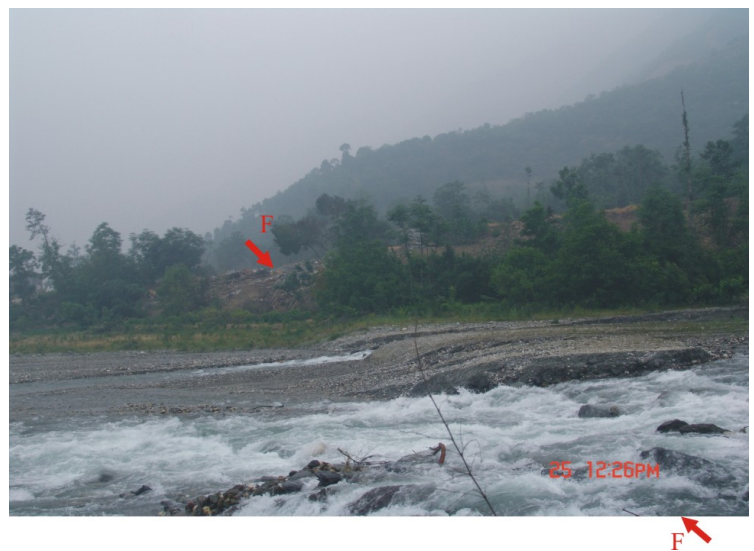

Figure 13. Waterfall was created by the surface rupture of the Wenchuan Earthquake in Pingtong town.

$1 \mathrm{~km}$ long and is $\mathrm{N} 50-60^{\circ} \mathrm{E}$ trending. The road, river terrace and the river bed are offset by the rupture (Figure 13). The vertical displacement of the road is about $1.9 \mathrm{~m}$.

All above facts indicated that the surface rupture on the Beichuan-Yingxiu fault showed the thrust, dextral slip characteristic of the fault. The maximum vertical displacement of the surface rupture is about $6.5 \mathrm{~m}$ and the maximum right-lateral displacement is about $5.85 \mathrm{~m}$. Though the vertical displacements and the horizontal ones of the different segments have certain differences, as a whole, the ratio of the vertical displacement and the horizontal is close to $1: 1$. This is consistent with the previous studies [12].

\subsection{The Surface Rupture on the Pengxian-Guanxian Fault}

The Pengxian-Guanxian fault is also called Pengguan fault [5]. The Wenchuan Ms8.0 earthquake occurred on $12^{\text {th }}$ May produced the coseismic surface rupture on this fault. The surface rupture begins near Xiangê town, Dujiangyan city. It sketches to the northeast, passes through Cifeng town in Pengzhou county, Bailu town, Jinhua town in Mianzhu city, Hanwang town, and breaks off near Sangzao town in Anxian county. The total length of it is about 50 kilometers.

1) The surface rupture of the Wenchuan Earthquake in Cifeng town

The southwest end of the surface rupture shows that the fault thrust from the northwest to the southeast and produced a reverse fault scarp. The rupture is $\mathrm{N} 10-50^{\circ} \mathrm{E}$ trending and shows a broad wave-like on the surface, with the length of 200-300 m. The heights of the fault scarps are between $0.24 \mathrm{~m}$ to $0.7 \mathrm{~m}$. The displacements of six ridges in the field are between $0.24 \mathrm{~m}$ to $0.5 \mathrm{~m}$ (Figure 14(a)). Here, the vertical displacements are slightly larger than the horizontal ones.

2) The surface rupture of the Wenchuan Earthquake in Bailu town

The surface rupture passes through between two teaching buildings of the central school in Bailu town, Pengzhou city. The height of the fault scarp is about $2 \mathrm{~m}$. According to measuring the length of superposition of the mattess, the shortening amount is $1.65 \mathrm{~m}$ (Figure 14(b)). The ruptures primarily present the thrust characteristic of the fault and the crustal shortening. It only shows a little horizontal displacement. Several gaps of the mattess are cut off and the maximum displacement is $0.42 \mathrm{~m}$. Northeast about $300 \mathrm{~m}$ to this spot, the river bed was cut off and produced a fault scarp with a height of $1.8 \mathrm{~m}$ (Figure 15(a)). The right-lateral offset of the bank of the river is about $0.8 \mathrm{~m}$ (Figure 15(b)) .

3) The surface rupture of the Wenchuan Earthquake in Jinhua town.

The surface rupture is $\mathrm{N} 65-70^{\circ} \mathrm{E}$ trending in Jinhua 

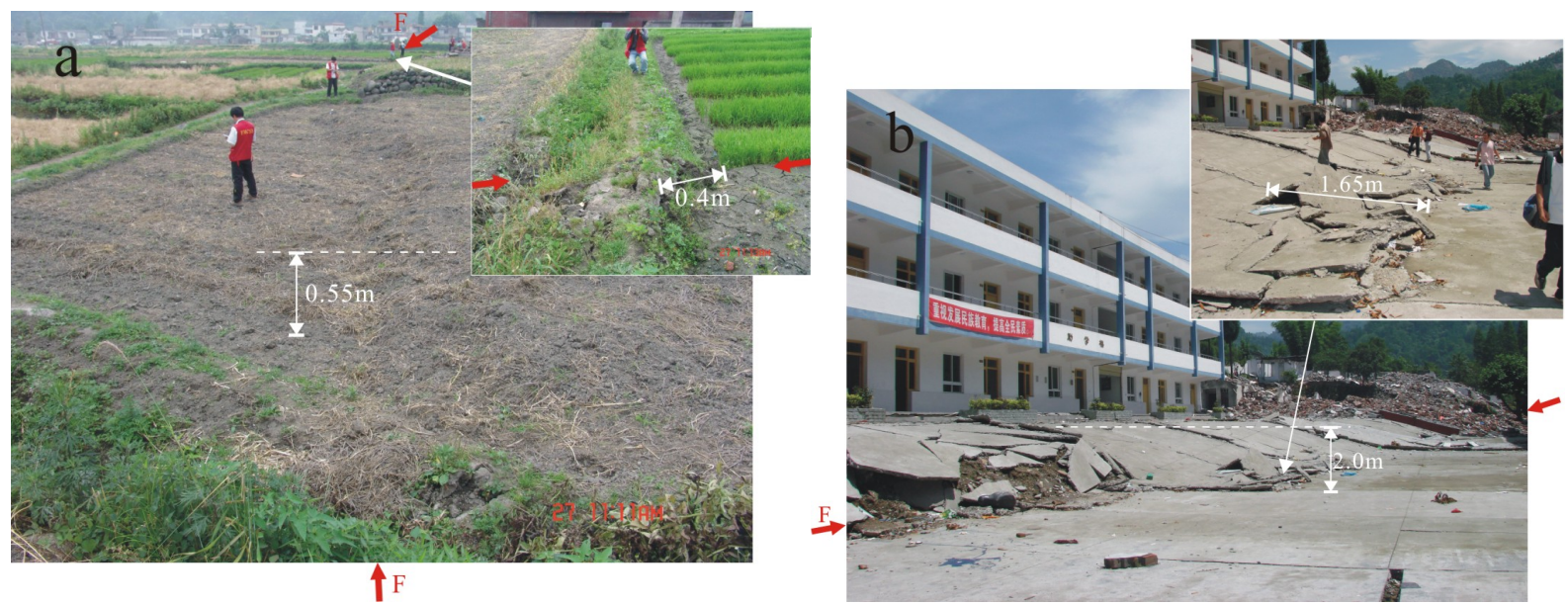

Figure 14. The surface rupture of the Wenchuan Earthquake in Cifeng town and Bailu central school. (a) the fault scarp and the offset of ridges in a field; (b) the fault scarp on the playground in the Bailu central school.
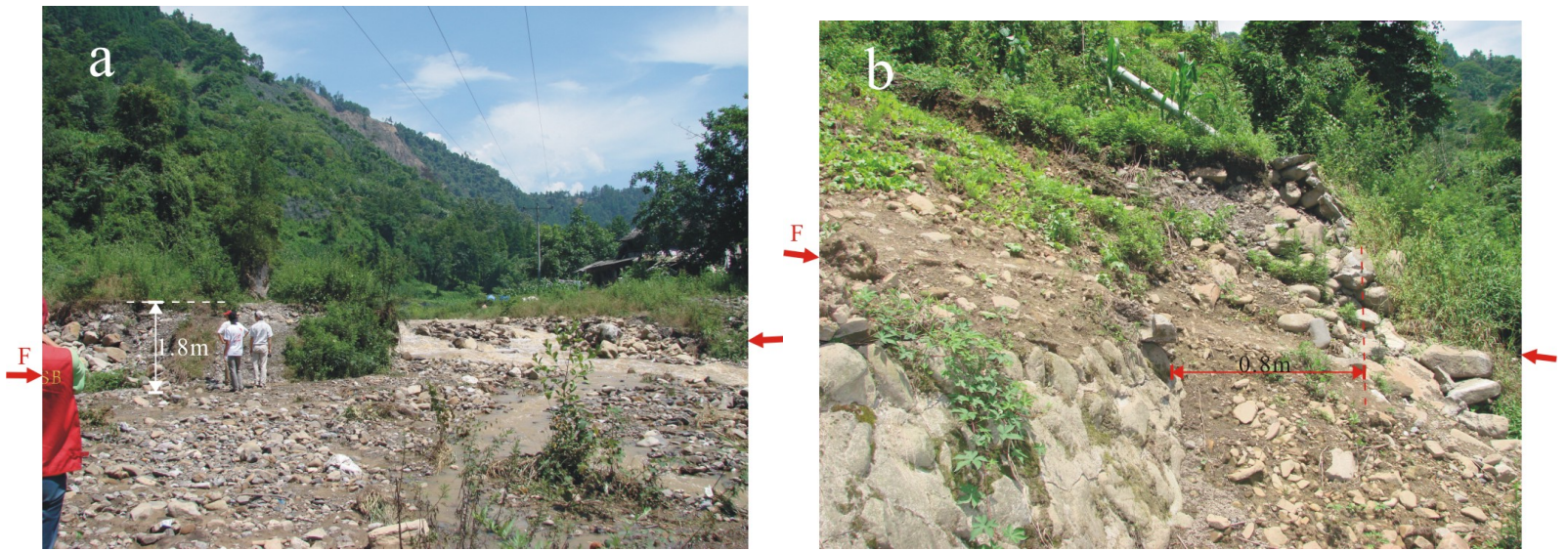

Figure 15. The surface rupture of the Wenchuan Earthquake on the riverbed and bank of Bailu river. (a) the fault scarp and waterfall on the riverbed was created by the Wenchuan Earthquake; (b) the right-lateral offset of the river bank.
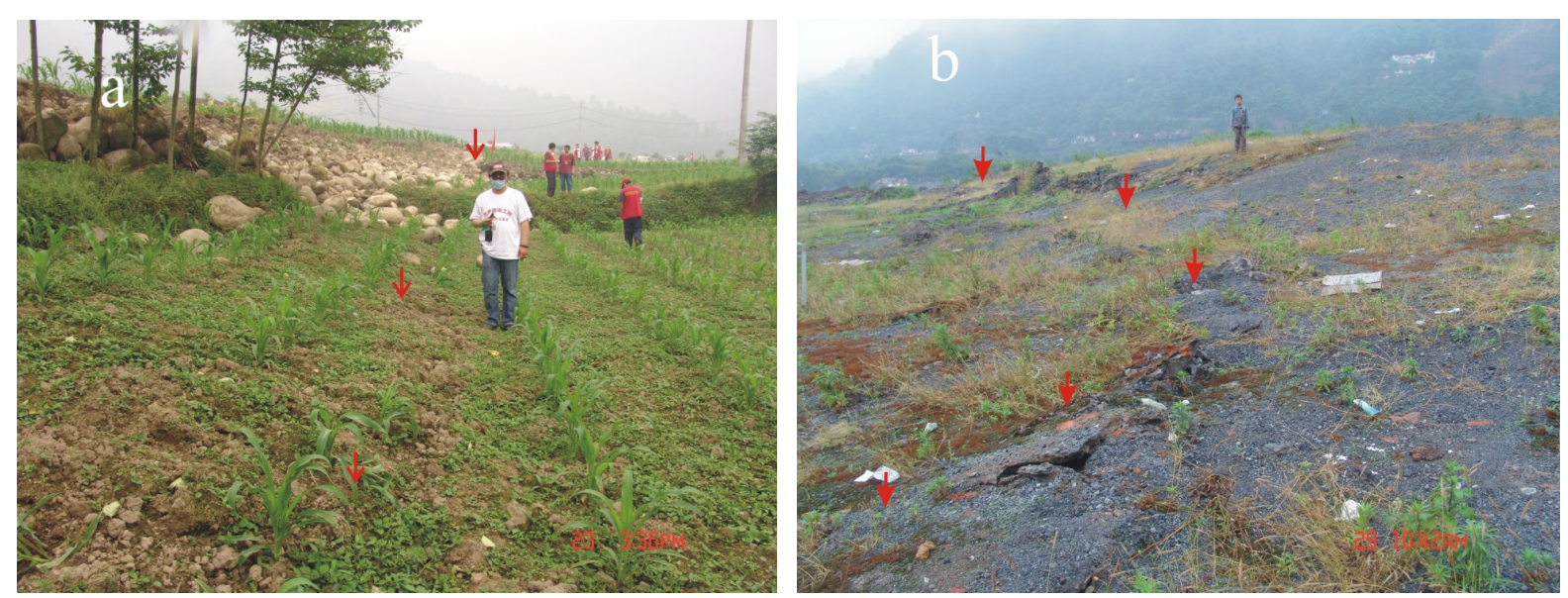

Figure 16. The surface rupture of the Wenchuan Earthquake in Jinhua and Hanwang town, Mianzhu county. (a) Scraps of the Penxian-Guanxian fault in Jinhua town; (b) Scraps of the Penxian-Guanxian fault in Hanwang town, the arrowheads show the location of the surface rupture

town, Mianzhu city (Figure 16(a)). The vertical displacement of the riverbed and terrace $\mathrm{I}$ is $1.5-2.0 \mathrm{~m}$. The right-lateral dislocation of the lateral edge of the terrace
I is $0.7 \mathrm{~m}$. The scarps on the surface of the terrace III are lower relatively and the heights of them are between $0.4 \mathrm{~m}$ and $0.7 \mathrm{~m}$. The dextral displacements of a pathway and 
the road are $0.18 \mathrm{~m}, 0.5 \mathrm{~m}$ respectively.

4) The surface rupture of the Wenchuan Earthquake in Hanwang town

The surface rupture is $\mathrm{N} 48^{\circ} \mathrm{E}$ trending in the north of Hanwang town, Mianzhu city (Figure 16(b)). The rightlateral dislocation of the road in the east bank of the Mianyuan River is $0.3-0.4 \mathrm{~m}$. The vertical displacement of a road in the west bank of the river is about $1.0 \mathrm{~m}$ and the dextral dislocation is $0.4-0.6 \mathrm{~m}$. The crustal shortening is $1.3 \mathrm{~m}$.

In a word, it believes that the surface rupture on the Pengxian-Guanxian fault shows thrust and dextral characteristic of the fault. The vertical displacements and the horizontal ones on some segments are approximately equal. But the rates of them on the most other segments are between 1:3 and 1:2. The maximum horizontal shortening is $1.65 \mathrm{~m}$. All of these show that the main characteristic of the fault rupture is thrust and shortening.

According to the surface rupture characteristic of the Wenchuan Ms8.0 earthquake on the Beichuan-Yingxiu fault and Pengxian-Guanxian fault, a seismogenic structures model of this earthquake can be made. The model shows that the inclination of the Beichuan-Yingxiu fault becomes flat gradually and disappears in the horizontal detachment layer about $20 \mathrm{~km}$ deep under the surface at last. The inclination of the Pengxian-Guanxian fault becomes flat too from the surface to the deep crust and converges with the Beichuan-Yingxiu fault at last. The collision of India-Asia Plate resulted in Sichuan-Qinghai block slipped to the NEE orientation. The activity of the Longmen Shan tectonic belt transformed brittle and thrust-dextral motion, accumulating tectonic stress. The hypocenter of the Wenchuan Ms8.0 earthquake is on the section of the Beichuan-Yingxiu fault, where the section of the fault up warped from the horizontal detachment layer. It simultaneously made the Pengxian-Guanxian fault produce coseismic dislocations (Figure 17).

\section{HAZARD OF THE WENCHUAN Ms8.0 EARTHQUAKE}

The primary hazard characteristics of the Wenchuan earthquake Ms8.0 are described as follows. 1) The seismic wave produced strong ground motion, destroying the structures. While the earthquake occurred, the writers were working in the seventh floor office in the urban district of Chengdu city. I could felt the strong vibration of the structure and the vibration lasted about two minutes. During this period, the vibration became weak obviously for 3-5 seconds. According to the seismological inversion for the spatiotemporal process of the earthquake's rupture, the first strong vibration that I felt was produced by the initial rupture of the fault near Yingxiu town. The rupture of the fault near Beichuan town resulted in the second strong vibration. 2) The earthquake produced a $220 \mathrm{~km}$ long surface rupture on the BeichuanYingxiu fault and a $50 \mathrm{~km}$ long one on the PengxianGuanxian fault. The surface ruptures cut off the structures and all of the structures close to the surface rupture zones almost broke down. The surface rupture zone pass through the central of the Pingtong town and all of the buildings in the rupture zone collapsed. The other structures with 30-50 m distance of the zone did not collapsed, only were severely or moderately destroyed.

3)The strong ground motion and the dislocation of the surface rupture resulted in the secondary geological hazards, such as landslip, collapse, and so on. The hazards pulled down or severely destroyed the structures. The earthquake occurred in the Longmen Shan area. Especially, the Beichuan-Yingxiu fault is the boundary fault between the higher modern geomorphology and the lower. The difference of the topographic height is very big. Thereby under the interaction of the strong ground motion and the dislocation of the surface rupture, the earthquake produced a large-area and large-scale landslide, collapse et al. in the high earthquake intensity regions of the Longmen Shan area. On the one hand, the landslides and collapse directly destroyed or buried large numbers of houses. For example, half of the houses were directly destroyed by the landslides. On the other hand, they blocked up the rivers and produced tens of sag lakes. Many croplands and houses were submerged. It formed a large potential threat of the flood disaster to the downstream region.

According to the investigations of the Earthquake Emergency Job Team of China Earthquake Administration, Seismological Bureaus of Gansu province, Shanxi province and Chongqing, it also made reference to the studies of InSAR and records of seismographs and rechecked the earthquake intensity of some major severely damaged regions. Basing on these studies, the isoseismal line of the Wenchuan Ms8.0 earthquake was drew (Figure 18). The isoseismal line only shows the general degree of the damages of this earthquake. And we did not considered the effect of the aggravated damages caused by the surface rupture.

1) XI intensity region: There are three XI intensity regions, occurring in Yingxiu-Hongkou, Yuejia ShanGaochuan and Xuanping-Beichuan area respectively. They distribute in the Beichuan-Yingxiu fault zone and its hanging wall. The total area of them is about $680 \mathrm{~km}^{2}$. The houses almost broke down in this area. Especially, the houses in the Yingxiu town and Beichuan county were completely destroyed. Individually, the un-collapsed houses were also severely destroyed. The scale of the surface is large and its continuity is generally well. The displacements of many segments are more than 3 meters. The earthquake resulted in multiple-site collapses and landslides. These second dary geological hazards walled up the rivers and produced the sag 


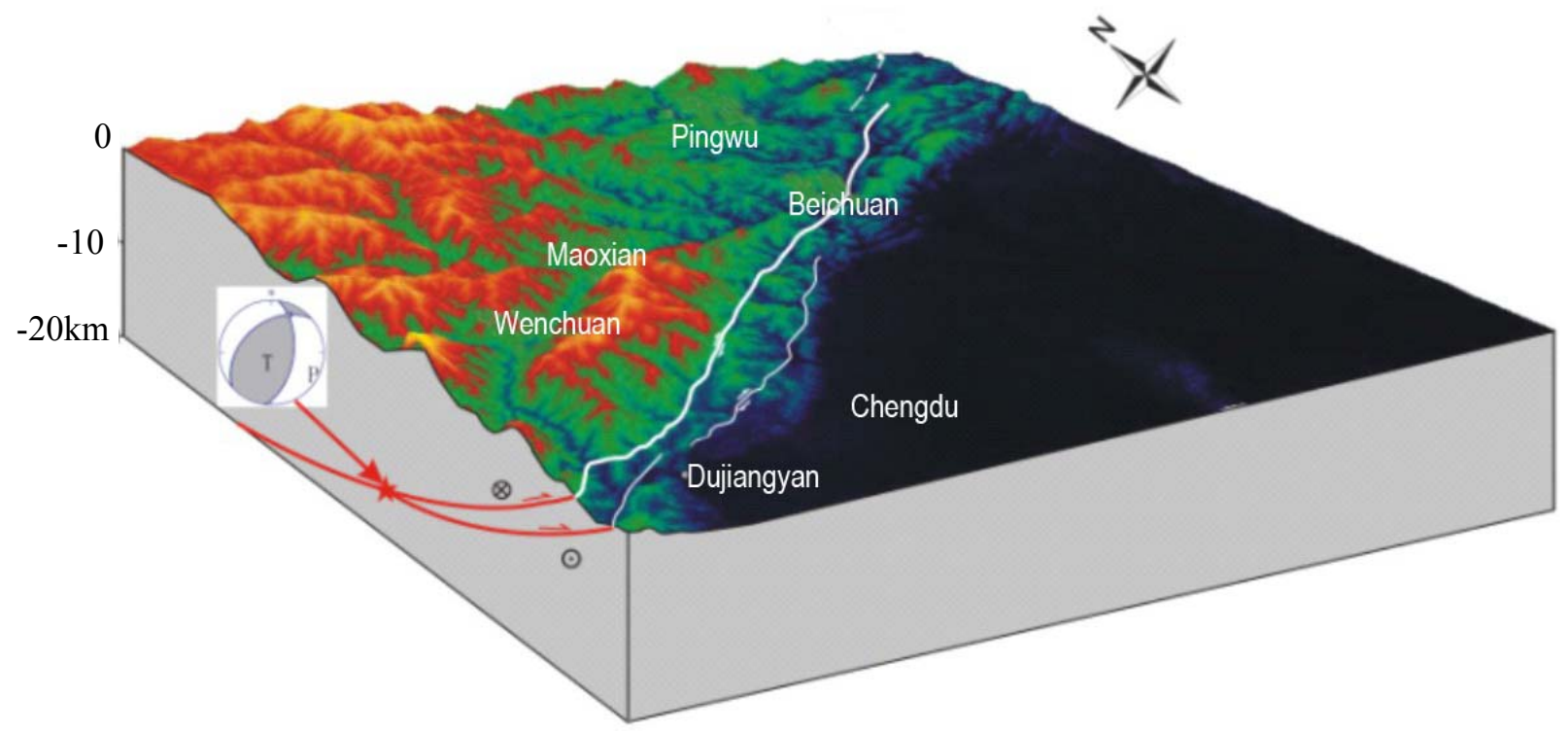

Figure 17. The seismogenic structures model of the Wenchuan Ms8.0 earthquake.

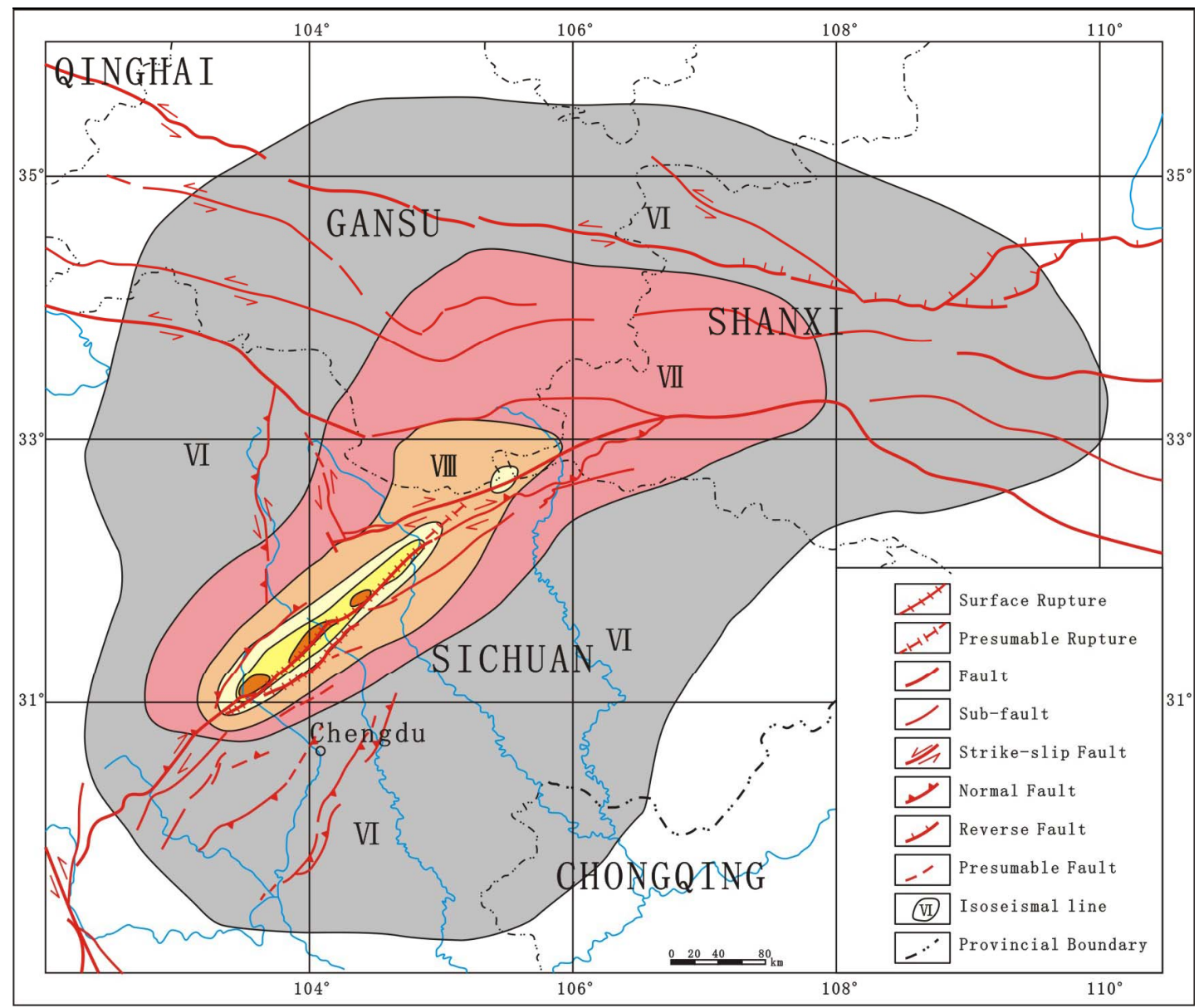

Figure 18. Isoseismal line of the Wenchuan Ms8.0 earthquake on $12^{\text {th }}$ May, 2008.

lakes, such as Qingping sag lake and Tangjia Shan sag lake in Beichuan county, and so on.
2) $X$ intensity region: The southwest part of the region begins in the southwest of the Yingxiu town. It 
sketches to the northeast and ends at Shikanzi village, Nanba town. The region includes the surface rupture extension of the Beichuan-Yingxiu fault. It distributes as a narrow area with a $\mathrm{N} 50^{\circ} \mathrm{E}$-trending long axis. The total area of the region is about $2520 \mathrm{~km}^{2}$. The houses in this region were generally destroyed and most of them were broken down. There are many huge landslides in this area.

3) IX intensity region: The region arises from Sanjiang town and Shuimo town, north-eastward to Shuiguan town, Fangshi town, south-eastward to Xicheng town, Hanwang town and Xiaoba town. A IX intensity abnormal region occurred in the VIII intensity region near the juncture area of Sichuan province, Gansu province and Shaanxi province. This area of the VIII intensity region sums up to $4000 \mathrm{~km}^{2}$. Most of the houses in there were severely destroyed and many of them collapsed. The collapses and landslides can be seen everywhere.

4) VIII intensity region: This region arises from Wenjing river, Heba village; north-eastward to Yangpingguan village; north-westward to Weimen village in Maoxian town, Pingwu, Wenxian town; south-eastward to Juyuan village, Mianzhu, Yanmen village in Jiange town. A VIII intensity abnormal region occurred in the Hanyuan county. The total area of the VIII intensity region is $17800 \mathrm{~km}^{2}$. Most of the houses in this region were severely or moderately destroyed, a little collapsed. The collapses and landslides are common too, but the scale of them is relatively small.

5) VII intensity region: This region arises from Dawei, north-eastward to Taibai, Foping village, north-westward to Shuangliusuo village in Heishui town, Zhenping town in Songpan county, Jiuzhaigou, Lixian county; southeastward to Deyang, Mianyang, Guangyuan city. The total area of this region is $68000 \mathrm{~km}^{2}$. Generally, the houses in this region are slightly destroyed. Many of them were moderately destroyed and a little were seriously destroyed. Individually, some adobe houses collapsed. There are some collapses and landslides in the region, but the scale of them is small.

6) VI intensity region: This region arises from Xiaojin, Tianquan village, north-eastward to Sanyuan, Shanyang village; north-westward to Hongyuan, Lintao, Jingning, Pingliang city; south-eastward to Jianwei town, Zigong, Hechuan county, Pingchang county. The total area of this region is $240000 \mathrm{~km}^{2}$. Most of the houses were slightly destroyed and a little were moderately destroyed. Individually, some adobe houses were severely destroyed. The collapses and landslides are rare in distribution in this area. Most of them are rolling stones or part of the slopes collapsing.

In a word, the total intensity area above VI degree of the Wenchuan earthquake is about $333000 \mathrm{~km}^{2}$. The characteristics of the isoseismal line are described as follows.

1) The high earthquake intensity line stretches to $\mathrm{N} 40-50^{\circ} \mathrm{E}$ along Longmen Shan tectonic belt. The rate of the long axis and the minor is between 8:1 and 10:1. Three XI intensity regions are isolated in distribution. It presents a multipoint instantaneous characteristic of the rupture.

2) According to the seismological inversion, the initial rupture of the fault is near Yingxiu town and cracked unilaterally north-eastward along Longmen Shan belt. The isoseismal line decayed rapidly south-westward and slowly norh-eastward. It is consistent with the unilateral rupture process.

3) The isoseismal line of VI intensity region decayed slowly to Sichuan basin, Hongyuan and Nuoergai county. The reason may be that Sichuan basin is in the rigid Yangtze Platform and seismic wave propagated difficultly. And the soft oil layer in the Hongyuan, Nuoergai area increased the hazard.

4) VI, VII and VIII intensity regions stretch to east-west in the north of Sichuan province, Guansu province and the south of Shaanxi province. The intensity of the earthquake may be under the control of the regional major faults.

\section{DISCUSSIONS}

1) It is generally believed that the Longmen Shan tectonic belt is a deep fault and the boundary fault between the Songpan-Garzê orogenic belt and the Yangtze Carton $[1,6,8]$. But there are different opinions on the late Quaternary activities of the Longmen Shan tectonic belt among different scholars. Tang [24] believed that some segments of the Longmen Shan tectonic belt were Holocene active faults, while the other segments were early Quaternary faults. Zhou [12] and Densmore [5] believed that most segments of the belt were Holocene active faults and Beichuan-Yingxiu fault was the major active fault. The acquaintanceship change among the scholars has been undergone for 15 years. The deeply incised topography, flourish vegetations, farmland reclamation and low slip rate of the fault make the field study and mapping more difficult and uncertain. Only a few clear active tectonic landforms were found on the Longmen Shan tectonic belt with length of $300 \mathrm{~km}$. Even so, most surface rupture of the Wenchuan earthquake outcropped along the locations of active tectonic landform of the Beichuan-Yingxiu fault found by the scholars before. The surface rupture did not outcrop along the linear structure discovered before near Xujiagou village, Longmen Shan town, but outcropped in the northwest of the linear structure with distance of $0.5-1.0 \mathrm{~km}$. Only a few seismic fractures cut into a sag-ponding discovered before. It presents the dextral slip characteristic of the secondary fault, distributing at an angle $5-10^{\circ}$ with the major fault. This may be relative to the strain partition of the complicated fault combination. The outcrop of the surface rupture on the Pengxian-Guanxian fault is more complicated. On the 1:200,000 regional geological map, there are several 
northwest-trending faults with different scales and lengths. It is difficult to confirm which is the major fault of the Pengxian-Guanxian fault. The surface rupture stretches through Bailu town with about $7 \mathrm{~km}$ distance southeastward the fault, not outcropping along the Holocene active fault in the Daiming temple in the Tongji town, Pengzhou county. It is very difficult to confirm the activity of the fault in Bailu town before the occurrence of earthquake. Therefore, the decision should be made cautiously for the activity of the faults in such region. A few phenomena of the geology and landform are important evidences to confirm the activity of the whole fault.

2) We have known the activity of several major faults of the Longmen Shan tectonic belt. Especially, BeichuanYingxiu fault is a Holocene active fault. Only 2-3 trenches in previous field work revealed the paleoearthquakes [3-5]. According to the historical data, only 3-4 earthquake events above Ms6.0 are recorded and the maximum is the Wenchuan Ms6.5 earthquake in 1657. These make us believe that the maximum potential magnitude of the earthquakes on the fault is about Ms7.0. Furthermore, the topographic responses of the active faults almost concentrate on the middle-south segment of the Longmen Shan tectonic belt. The historical strong earthquakes and modern small-moderate earthquakes are dense in a belt along this segment. The seismicities on the middle-north segment are weak. The gradient zone of the crustal thickness along the Longmen Shan tectonic belt changes from NE to NNE near Beichuan county and stretches along the east boundary of the Minshan block. The topography and geomorphology relatively changed there. Therefore, the boundary of the subsection of the Longmen Shan tectonic belt is near Beichuan county [25]. The surface rupture of the earthquake broke through the limit of the fault subsection and stretched north-eastward to $30-40 \mathrm{~km}$. It teminated at Shikanzi village, Nanba town. The earthquake not only produced about $220 \mathrm{~km}$ long surface rupture on the Beichuan-Yingxiu fault, but also about $50 \mathrm{~km}$ long one on the PengxianGuanxian fault. Thus, we should fully consider the scale of active faults on determination of the potential earthquake resource according to sections of active faults. We can't confirm the upper-limit magnitude of the potential earthquake resource through increasing the magnitude of the maximum historical earthquake. Furthermore, it should be fully demonstrated that the boundary of fault subsections could control the propagation of strong earthquakes' rupture permanently. And it should be recognized that several faults in the reverse or reverse-slip tectonic circumstance would be likely to crack coinstantaneously in a strong earthquake. This should be considered for determination of the potential earthquake resource.

3) The unilateral multipoint instantaneous rupture of the earthquake increased the hazards in the north of Sichuan province, Gansu province and the south of Shanxi province. The VI intensity region attenuated slowly to the Sichuan basin, Hongyuan and Nuoergai county. It presents a special attenuation characteristic of strong earthquake. According to 'National Standard of the People's Republic of China. Seismic ground motion parameter zonation map of China' (GB18306-2001) [26], the area where the surface rupture outcrop are all the partitions of ground motion parameter 0.1 gal. It is incompatible with the article of 'National Standard of the People's Republic of China. Code for Seismic Design of Buildings' (GB50011-2001) [27]. In this article, it is considered that the causative fault could be neglectable in the earthquake intensity region under VIII degree. This is because the interval recurrence of the great earthquakes above Ms8.0 is beyond a thousand years or several thousand years. And the peak acceleration of the ground motion could not reach VIII degree in 500yr interval recurrence. Moreover according to the investigation of this earthquake, the structures in the surface rupture zone almost collapsed or severely destroyed. The other structures with 30-50m distance of the zone did not collapse (such as the structures in Hongkou, Jinhua, Pingtong town et al.). There is obvious difference in the criterion (GB50011-2001) [27] that the preventing belt should be $200 \mathrm{~m}$ to the causative fault for the third class buildings in the VIII intensity region. So, it is suggested to cancel the criterion that didn't consider preventing the causative fault under VIII intensity region. We should mainly consider the Holocene active faults. The preventing distance to the causative fault could be modified basing on this earthquake and making reference to the overseas great earthquakes' datum.

4) According to the surface rupture characteristics of the earthquake, the Beichuan-Yingxiu fault is a dextral-slip and thrust fault and the vertical displacement on it is equal to the horizontal. The Pengxian-Guanxian fault is thrust fault with a little dextral-slip component. The slip rates of the major faults of the Longmen Shan tectonic belt are not accurate enough. And the paleoearthquakes is not enough for the determination of the upper-limit magnitude. According to the records of 'Compilation of Historical Data of Earthquakes in China' (Edited by Xie [28]), there were eleven historical earthquakes during May 934A.D. to April-May 953 A.D.. Among them, two earthquake caused serious destroy. One occurred during Nov.16 to Dec.15, 942 A.D.. The other occurred during Nov.7 to Dec.6, 951 A.D.. Considering the bad quality of dwellers' houses at that time, the damage caused by the two historical earthquakes showed that the intensities reached VI-VII degree. It is equivalent to the effect of Chengdu city caused by the Wenchuan Ms 8.0 earthquake. Densmore [5] excavated a trench in Xiling town with distance about $70-80 \mathrm{~km}$ to Chengdu city. The ${ }^{14} \mathrm{C}$ ages constrain the timing of the last paleoearthquake event to $860 \pm 40-930 \pm 40 \mathrm{yr}$ B.P.. The A.D. year is $1090 \pm 40-1020 \pm 40$ yr. It is 
nearly equivalent to the historical earthquake as mentioned above. Does it imply that a great earthquake with equivalent magnitude as the Wenchuan Ms8.0 earthquake occurred a thousand years ago? The Wenchuan Ms8.0 earthquake provides an opportunity to solve these questions. There is very important scientific and practical meaning for the seismic risk assessment of the Longmen Shan tectonic belt and its adjacent areas and the earthquake disaster prevention of Chengdu Plain with a large population density.

\section{ACKNOWLEDGMENT}

We are very grateful to the people who provided us supports and help. Finally, we thank the people of the Longmen Shan region for their unending curiosity, hospitality, and generosity.

\section{REFERENCES}

[1] Burchfiel, B.C., Chen, Z., Liu, Y. and Royden, L.H. (1995) Tectonics of the longmen shan and adjacent regions. International Geology Review, 37, 661-735.

[2] Kirby, E., Whipple, K.X., Tang, W. and Chen, Z. (2003) Distribution of active rock uplift along the eastern margin of the tibetan plateau:Inferences from bedrock channel longitudinal profiles. Rnal geophysical research, 108(B4), 2217.

[3] Li, Y., Zhou, R.J., Alexander, L., Densmore, L.A., et al. (2006) Continental dynamic processes and geological response in the eastern margin of the Qinghai-Tibet plateau [A]. Geological Publishing House, Beijing, 1-134 (in Chinese).

[4] Zhou, R.J., Li, Y., Alexander, L., Densmore, A.L., Michael, A., Ellis, M.A., He, Y.L., Li, Y.Z. and Li, X.G. (2007) Active tectonics of the longmen shan region on the eastern margin of the Tibetan plateau [J]. ACTA Geologica Sinica, 81(4), 593-604.

[5] Densmore, A.L., Ellis, M.A., Li, Y., Zhou, R.J., Hancock, G.S. and Richardson, N.J. (2007) Active tectonics of the Beichuan and Pengguan faults at the eastern margin of the Tibetan Plateau. Tectonics, TC4005.

[6] Xu, Z.Q., Hou, L.W., and Wang, Z.X. (1992) The orogenic process of Songpan-Ganzi orogenic belt in China. Geology Press, Beijing.

[7] Chen, S.F., Deng, Q.D., Zhao, X.L., Wilson, C.J.L., Dirks, P., Luo, Z.L. and Liu, S.Y. (1994) Deformational characteristics evoloutionary history, and deformation mechanism of the middle Longmenshan thrust-nappes and related tectonics. Seismology and Geology, 16(4), 404-421.

[8] Li, Y., Zeng, Y.F. and Yi, H.S. (1995) Sedimentary record and tectonic evolution of Longmen Shan foreland basin. Chengdu University of Science and Technology Press [A], Chengdu, 1-9 (in Chinese).

[9] Avouac, J.P. and Tapponnier, P. (1993) Kinematic model of active deformation in Central-Asia. Geophysical Research Letters, 20, 895-898.

[10] Zhang, P.Z., Sheng, Z.K., Wang, M., Gan, W.J., Brügmann, R., Monlar, P., Wang, Q., Niu, Z.J., Sun, J.Z.,
Wu, J.C., Sun, H.R. and You, X.Z. (2004) Continuous deformation of the Tibetan Plateau from global positioning system data. Geology, 32, 809-812.

[11] England, P.C. and Molnar, P. (1990) Right-lateral shear and rotation as the explanation for strike-slip faulting in eastern Tibet. Nature, 344, 140-142.

[12] Zhou, R.J., Li, Y., Densmore, A.L., Ellis, M.A., He, Y,L., Wang, F.L. and Li, X.G. (2006) Active tectonics of the eastern margin of the Tibet plateau. Journal of Mineral Petrol, 26(2), 40-51.

[13] Li, Y., Huang, R.Q., Zhou, R.J., Densmore, A.L, Yan, L., Zhang, Y., Nicholas, R., Dong, S.L., Michael, A., Ellis, He, Y.L., Chen, H, Qiao, B.C. and Ma, B.L. (2009) The surface rupture of the Xiaoyudong fault in the Wenchuan Earthquake and its geological significance, Longmen Shan, Sichuan, China. Quaternary Sciences, 29(3), 506-516.

[14] Xu, X.W., Wen, X.Z., Ye, J.Q., Ma, B.Q., Chen, J., Zhou, R.J., He, H.L., Tian, Q.J., He, Y.L., Wang, Z.C., Sun, Z.M., Feng, X.J., Yu, G.H., Chen, L.C., Chen, G.H., Yu, S.N., Ran, Y.K., Li, X.G., Li, C.X. and An, Y.F. (2008) The Ms8.0 Wenchuan Earthquake surface ruptures and its seismogenic structure. Seismology and Geology, 30(3), 597-629.

[15] Liu, J., Zhang, Z.H., Wen, Li., Sun, J., Xing, X.C., Hu, G.Y., Xu, Q., Paul, T.E., Zeng, L.S., Ding, L. and Liu, Y.L. (2008) The Ms8.0 Wenchuan Earthquake. Coseisimic surface rupture and its tectonic implication- an out-of -sequence thrusting event with partitioned on multiple faults. Acta Geologica Sinica, 82(12), 17071722.

[16] Chen, G.H., Xu, X.W., Zheng, R.Z., Yu, G.H., Li, F., Li, C.X., Wen, X.Z., He, Y.L., Ye, Y.Q., Chen, X.C. and Wang, Z.C. (2008) Quantitative analysis of the co-seismic surface rupture of the $2008 \mathrm{Ms} 8.0$ Wenchuan Earthquake, Sichuan China along the Beichuan-Yingxiu fault. Seismology and Geology, 30(3), 723-738.

[17] Li, Y., Zhou, R.J., Dong, Densmore, A.L., Yan, L., Zhang, Y., Richardson, N., Dong, S.L., Ellis, M.A., He, Y.L., Chen, H., Qiao, B.C. and Ma, B.L. (2008) Surface rupture, thrusting and strike-slipping in Wenchuan earthquake of Sichuan, China. Journal of Chengdu University of Technology, 35(4), 404-413.

[18] Li, Y., Zhou. R.J., Densmore, A.L., Yan, L., Zhang, Y., Richardson, N., Dong, S.L., Ellis, M.A., He, Y.L. Chen, H., Qiao, B.C. and Ma, B.L. (2008) Surface Rupture and Deformation of the Yingxiu Beichuan Fault by the Wenchuan Earthquake. Acta Geologica Sinica, 82(12), 1688-1706.

[19] Li, Y., Zhou, R.J., Densmore, A.L., Yan, L., Zhang, Y.,. Richardson, N., Dong, S.L., Ellis, M.A. He, Y.L., Chen, H., Qiao, B.C., and Ma, B.L. (2009) Geological background of Longmen Shan seismic belt and surface ruptures in Wenchuan Earthquake. Journal of Engineering Geology, 17(1), 3-18.

[20] Li, Y., Zhou, R.J., Densmore, A.L. Yan, L., Zhang, Y., Richardson, N., Dong, S.L., Ellis, M.A., He, Y.L., Chen, H., Qiao, B.C. and Ma, B.L. (2009) Active tectonics and surface rupture of the Pengxian-Guanxian Fault, Longmenshan, Sichuan, China. Quaternary Sciences, 29(3), 405-417. 
[21] Li, H.B., Fu, X.F., Woerd, J.V.D., Si, J.L.,Wang, Z.X., Hou, L.W., Qiu, Z.L., Li, N., Wu, F.Y. and Xu, Z.Q. (2008) Co-seisimic surface rupture and dextral-slip oblique thrusting of Ms8.0 Wenchuan Earthquake. Acta Geologica Sinica, 82(12), 1623-1643.

[22] Fu, B.H., Shi, P.L., Wang, P., Li, Q., Kong, P. and Deng, G.D. (2009) Geometry and kinematics of the 2008 Wenchuan earthquake surface ruptures around the Qushan Town of Beichuan County, Sichuan: Implications for mitigation of seismic and geologic disasters. Chinese Journal of Geophysics, 52(2), 485-495.

[23] Ran, Y.K., Chen, L.C., Chen, G.H., Yin, J.H., Chen, J., Gong, H.L., Shi, X. and Li, C.X. (2008) Primary analyses of in-situ recurrence of large earthquake along seismogenic fault of the Ms8.0 Wenchuan Earthquake. Seismology and Geology, 30(3), 630-634.

[24] Tang, R.C. and Han, W.B., Ed. (1993) Active Faults and Earthquakes in Sichuan Province. Seismological Press, Beijing, 368.
[25] Chen, G.G., Ji, F.J., Zhou, R.J., Xu, J., Zhou, B.G., Li, X.G. and Ye, Y.Q. (2007) Primary research of activity segmentation of Longmenshan fault zone since later quaternary. Seismology and Geology, 29(3), 657-673.

[26] State Bureau of Quality and Technical Supervision. (2001) National Standard of the People's Republic of China. Seismic grouond motion parameter zonation map of China [A].1-2 (in Chinese).

[27] Ministry of Housing and Urban-Rural Development of the People's Republic of China, General Administration of Quality Supervision, Inspection and Quarantine of the People's Repubilic of China. (2001) National Standard of the People's Republic of China. Code for Seismic Design of Buildings [A]. China Architecture \& Building Press, Beijing, 17 (in Chinese).

[28] Xie, Y.S. and Cai, M.B. (1983) Compilation of historical data of earthquakes in China (the first volume) [A]. Science Press, Beijing, 105-107 (in Chinese). 